\title{
Diagnosing Pulmonary Embolism in Patients with Suspected or Established Chronic Lung Disease
}

\author{
Robert B Tompkins MD, Vaughn Harris MD, Clayton Brown MD, David E Griffith MD
}

\begin{abstract}
We recently identified four patients with pulmonary embolism (PE) who presented with progressive, but nonspecific, respiratory symptoms and were initially diagnosed with an exacerbation of established or presumed airflow obstruction. No specific explanation for the apparent respiratory exacerbation was found and each patient failed to respond to bronchodilator and/or antibiotic therapy, thereby triggering an evaluation for $P E$. Pulmonary embolism occurs with disturbing frequency in the setting of an apparent chronic airflow obstruction exacerbation without a clear explanation. Suspicion of PE by the clinician is essential as patient symptoms and routine laboratory evaluation do not always differentiate $P E$ from exacerbation of airflow obstruction. D-dimer determination is a reasonable first diagnostic step with subsequent testing directed by the $D$-dimer result in the context of an individualized assessment of PE risk. The diagnosis of PE in this setting is critically important for avoiding the attendant morbidity and mortality associated with untreated PE.
\end{abstract}

Key words: COPD, pulmonary embolus, diagnosis

\section{INTRODUCTION}

The classic clinical presentation of acute pulmonary embolism (PE) is familiar to most clinicians. When a patient with known risk factors for thromboembolic disease, such as malignancy, recent surgery, or immobilization, presents with unilateral lower extremity edema and/or inflammation, acute shortness of breath, pleuritic chest pain, and tachycardia, PE quickly rises to the top of the differential diagnosis list, and the appropriate workup is initiated. Unfortunately, these ideal clinical circumstances are frequently not present in patients with PE, especially in those with suspected or diagnosed underlying lung disease.

Corresponding author: Robert B. Tompkins MD Contact Information: Robert.tompkins@uthct.edu DOI: 10.12746/swrccc2014.0208.097
Consequently, PE may be initially overlooked in favor of empiric treatment for an exacerbation of underlying lung disease. In fact, in patients with chronic obstructive pulmonary disease (COPD) who present with a presumed COPD exacerbation, there are no significant differences in symptoms between patients with and without PE. ${ }^{1-3}$ Given these difficulties, PE should be included in the differential diagnosis for COPD patients when the clinical presentation is not readily explained by common factors that exacerbate airflow obstruction, such as bronchospasm, pneumonia, or heart failure, or for patients who do not readily improve with targeted therapy for these common exacerbating factors. The timely diagnosis of PE is further complicated by a paucity of tests that are sensitive and specific for diagnosing $P E$ in patients with chronic airflow obstruction. The consequences of missed diagnosis of PE for patients with chronic lung disease 
can be dire and include increased risk for recurrent $\mathrm{PE}$, increased short and long term mortality, aggravated pulmonary hypertension, and right ventricular dysfunction.

We recently encountered four non-smoking patients with previously diagnosed or suspected airflow obstruction who were admitted with respiratory deterioration and were ultimately diagnosed with PE. The major objective of this manuscript is to review circumstances in which acute and/or recurrent PE might occur in patients with established or suspected airflow obstruction. These circumstances notably include an apparent exacerbation of the patient's airflow obstruction with no identifiable exacerbating factor(s) or poor response to therapy directed at exacerbating factors for airflow obstruction. We also suggest diagnostic strategies for PE under these circumstances.

\section{Case Presenttion}

Patient case summaries are presented in Table 1.

Table 1: Case summaries

\begin{tabular}{|c|c|c|c|c|}
\hline & Patient A & Patient B & Patient C & Patient D \\
\hline Patient Characteristics & $\begin{array}{l}\text { 77-year-old } q \\
\text { Non-smoker } \\
\text { BMI-39 } \\
\text { OSA }\end{array}$ & 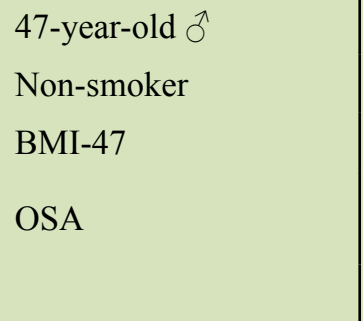 & $\begin{array}{l}63 \text {-year-old } 0 \\
\text { Non-smoker with } \\
\text { COPD } \\
\text { Knee replacement } 5 \\
\text { months prior } \\
\text { BMI-36, OSA }\end{array}$ & $\begin{array}{l}\text { 52-year-old }+ \\
\text { Nonsmoker } \\
\text { Estradiol HRT } \\
\text { Chronic asthma } \\
\text { BMI-67 }\end{array}$ \\
\hline Presenting Complaint & $\begin{array}{l}\text { Pleuritic chest pain } \\
\text { exertional dyspnea }\end{array}$ & $\begin{array}{l}1 \text { month progressive } \\
\text { exertional dyspnea } \\
\text { cough }\end{array}$ & $\begin{array}{l}1 \text { year progressive } \\
\text { cough, dyspnea, } \\
\text { pleuritic chest pain }\end{array}$ & $\begin{array}{l}4 \text { months of worsening } \\
\text { dyspnea } \\
\text { pleuritic chest pain }\end{array}$ \\
\hline $\begin{array}{l}\text { Presumptive diagnosis } \\
\text { and initial therapy }\end{array}$ & $\begin{array}{l}\text { Polymyalgia rheumatica } \\
\text { and presumed malig- } \\
\text { nancy } \\
\text { Treatment: } \\
\text { Prednisone }\end{array}$ & $\begin{array}{l}\text { Respiratory tract infec- } \\
\text { tion } \\
\text { Treatment: Antibiotics, } \\
\text { bronchodilators, and } \\
\text { steroids }\end{array}$ & $\begin{array}{l}\text { Pneumonia } \\
\text { Treatment: Antibiotics, } \\
\text { bronchodilators }\end{array}$ & $\begin{array}{l}\text { Worsening chronic } \\
\text { asthma; respiratory } \\
\text { infection } \\
\text { Treatment: Steroids, } \\
\text { bronchodilators, and } \\
\text { antibiotics }\end{array}$ \\
\hline D-dimer & Not done & Not done & $>500 \mathrm{ng} / \mathrm{ml}$ & $<250 \mathrm{ng} / \mathrm{ml}$ \\
\hline $\begin{array}{l}\text { CT Pulmonary Angio- } \\
\text { gram }\end{array}$ & $\begin{array}{l}\text { Bilateral minimally oc- } \\
\text { clusive and non-occlu- } \\
\text { sive thrombi }\end{array}$ & $\begin{array}{l}\text { Heavy burden of PE } \\
\text { bilaterally involving all } \\
\text { lobar pulmonary arteries }\end{array}$ & $\begin{array}{l}\text { Extensive bilateral non- } \\
\text { occlusive and occlusive } \\
\text { pulmonary emboli }\end{array}$ & $\begin{array}{l}\text { Moderate burden of } \\
\text { pulmonary embolism } \\
\text { bilaterally }\end{array}$ \\
\hline Treatment & $\begin{array}{l}\text { Lovenox } \\
\text { Warfarin }\end{array}$ & $\begin{array}{l}\text { Lovenox } \\
\text { Warfarin x } 6 \text { mo }\end{array}$ & Rivaroxaban & $\begin{array}{l}\text { Rivaroxaban; } \\
\text { Estradiol discontinued }\end{array}$ \\
\hline
\end{tabular}




\section{Discussion}

Pulmonary embolism in patients with COPD is not rare. The reported incidence from older studies of $\mathrm{PE}$ found post mortem in COPD patients ranged from $28 \%$ to $51 \%$. ${ }^{12-13}$ More recent studies suggest that the true frequency of PE in COPD patients in whom $\mathrm{PE}$ is clinically suspected ranges from $19 \%$ to $29 \%$.

Lesser and colleagues examined the characteristics of 108 patients with COPD and suspected PE, of whom $19 \%$ (21/108) were diagnosed with PE. ${ }^{14}$ In addition, Tille-Leblond, et al. found that in a series of 197 consecutive patients with COPD referred for severe exacerbation of unknown origin, $25 \%$ had PE on $\mathrm{CT}^{2}{ }^{2}$ Risk factors and clinical symptoms, such as change in dyspnea, pleuritic pain, hemoptysis, tachycardia and lower extremity edema, were no more associated with PE than with COPD without PE. The level of hypoxemia, the level of $\mathrm{pCO}_{2}$, and the alveolar-arterial (A-a) gradient were also no more associated with $\mathrm{PE}$ than with COPD without PE. However, a decrease in $\mathrm{PCO}_{2}$ of at least $5 \mathrm{~mm}$, previous thromboembolic disease, and malignant disease were associated with PE. Because the symptoms of PE and COPD exacerbation are essentially identical, it is not surprising that the possibility of PE in patients with COPD is sometimes over-looked. Patients with chronic airflow obstruction are at risk for other manifestations of venous thromboembolic disease. Shetty, et al. found that patients admitted for acute COPD exacerbation were at increased risk for DVT because of immobilization, advanced age, smoking, underlying malignancy, and RV failure. ${ }^{15}$ They identified 668 patients with COPD and DVT and compared them with 4000 patients with DVT but without COPD. Patients with COPD and DVT were likely to be older, male, inpatient in the ICU on mechanical ventilation, with an IVC filter, and with greater medical acuity. Stein, et al. found that VTE ( $P E$ and $D V T$ ) is frequently under-diagnosed in patients with COPD and that the relative risk is higher in younger patients compared to older patients who often have multiple other risk factors for VTE. ${ }^{16}$

Previously published identifiable risk factors for PE include immobilization, surgery within three months, stroke, paresis, paralysis, central venous instrumentation within three months, malignancy, chronic heart disease, autoimmune diseases, history of venous thromboembolism, obesity in women, cigarette smoking, and hypertension. ${ }^{17-19}$ Chronic obstructive pulmonary disease is not included on that list, although patients with chronic airflow obstruction with hypoxia may have subclinical or overt pulmonary hypertension and RV dysfunction, which then promotes venous stasis and thromboembolism. Similarly, obstructive sleep apnea (OSA), a disease associated with chronic hypoxia and common to the patients in this report, has recently been associated with increased risk of venous thromboembolic disease and hypercoagulability. ${ }^{2021}$ The apparent association of venous thromboembolic disease and OSA is particularly worrisome due to the frequent under-diagnosis of OSA.

At some point during the hospitalization of a patient with an exacerbation of diagnosed or presumed airflow obstruction, the question must be asked: is there an explanation for this respiratory exacerbation and is the patient responding (improving) appropriately to the therapeutic regimen? For the majority of patients presenting with apparent airflow obstruction exacerbation, the answers will be affirmative. However, for patients without an identifiable etiology for airflow obstruction exacerbation, or for those who are not responding appropriately to therapy directed at the assumed exacerbating factor, consideration must be given to the possibility of PE. While there is literature about the occurrence of PE with underlying COPD, there is little published about PE in the presence of other chronic lung diseases, such as pulmonary fibrosis or bronchiectasis. Presumably, the same considerations would be pertinent for those disorders as well; that is, PE should be suspected in the absence of a clear exacerbating factor or with poor response to usual or "standard" therapy.

There are significant consequences for missing the diagnosis of PE. Untreated PE is associated with a mortality rate of approximately $30 \%$ with recurrent PE the most common cause of death. ${ }^{5.7}$ Pulmo- 
nary embolism also increases the rate of death from COPD at one year. ${ }^{22}$ Persistent RV dysfunction is also more likely associated with a recurrent $\mathrm{PE}$, recurrent DVT, and a two fold increase in PE-related mortality compared to patients with no RV dysfunction or RV dysfunction with regression.

The diagnosis of an acute pulmonary embolism is a clinical challenge in the setting of underlying lung disease because many of the symptoms are vague and non-specific, physical findings can be lacking, and diagnostic tests have limited sensitivity and specificity. ${ }^{1-3}$ It cannot be overstated that the most important aspect of PE diagnosis in the setting of established or even presumed underlying lung disease is suspicion of the diagnosis. Routine tests such as arterial blood gases (ABGs), electrocardiograms (ECGs), chest radiographs, complete blood counts (CBC), and chemistry profiles are usually not helpful in the diagnosis of PE. If prior or baseline $A B G s$ are available, a reduction in the $\mathrm{PCO}_{2}$ level of $>5 \mathrm{~mm}$ is significantly associated with PE in COPD patients. ${ }^{2}$

Prior to the advent of helical-CT angiography, ventilation-perfusion (V/Q) lung scanning was the only non-invasive radiographic study for diagnosing pulmonary embolism. Ventilation-perfusion scans are helpful for excluding PE in patients with low pre-test probability of PE and low-probability scan results. Alternatively, they are also helpful in diagnosing patients with high pre-test probability of PE and high-probability scan results. ${ }^{23}$ However, it is well-recognized that the V/Q scan is sometimes limited in usefulness for patients with underlying lung diseases that are associated with severe and sometimes diffuse V/Q mismatching, resulting in $V / Q$ scan abnormalities that cannot be distinguished from those caused by PE. A normal $V / Q$ scan virtually excludes PE. However, that is a rare finding in patients with underlying lung disease.

Doppler-ultrasound evaluation of the lower extremities for evidence of DVT can give additional evidence to help diagnose or exclude PE. In patients with symptoms, elevated D-dimer and an ultrasoundDoppler positive for DVT, the diagnosis of PE is quite probable and treatment can be started. An ultrasoundDoppler that is negative for DVT does not exclude the diagnosis of $P E$ in patients with symptoms or risk factors for PE. In one series, lower extremity ultrasound identified $51 \%$ of patients with PE in the setting of unexplained COPD exacerbation by diagnosing a lower extremity DVT. ${ }^{2}$

The blood test for fibrin split products, D-dimer, is usually elevated in PE with sensitivities ranging from $85-98 \%$ but with low specificity in the range of $40 \%{ }^{24-26}$ Evidence indicates that a D-dimer level $<500 \mathrm{ng} / \mathrm{mL}$ is sufficient to exclude PE in patients with a low clinical pretest probability of $P E$. A negative $D$ dimer is not sufficient to exclude PE in patients with a high pretest probability of $\mathrm{PE}$ and has variable performance for those with a moderate pretest probability of $P E{ }^{24-25}$ A positive result requires further assessment in order to diagnose or rule out PE. D-dimer levels can be high among hospitalized patients, especially those with malignancy or recent surgery. ${ }^{26-27}$ Table 2 is a partial list of disorders associated with increased plasma levels of fibrin D-dimer. Quantitative ELISA and semi-quantitative latex agglutination ("sensitive D-dimer testing") are preferred because their high negative predictive value indicates that they are superior to erythrocyte agglutination for excluding $P E .^{28}$ There is no evidence COPD, per se, alters D-dimer determination. $^{29}$

Brain natriuretic peptide (BNP) levels are typically increased in patients with $P E$ compared to patients without PE. However, many patients with PE do not have elevated BNP, and there are many alternative causes of an elevated BNP. ${ }^{30-32}$ BNP levels do predict RV dysfunction and mortality. In one study, short-term mortality was increased six times among patients with BNP $>100 \mathrm{pg} / \mathrm{ml}$ and 16 times among patients with an NT-pro BNP > $600 \mathrm{pg} / \mathrm{ml}^{32}$

Helical CT scanning is now the most frequently used test for evaluating PE in patients with normal renal function. It can quickly evaluate for intraluminal filling defects within the pulmonary arterial tree with high sensitivity for PE in the lobar or main pulmonary arteries. $^{33-35}$ This test may be non-diagnostic when the 
Table 2: Conditions associated with elevated D-Dimer levels

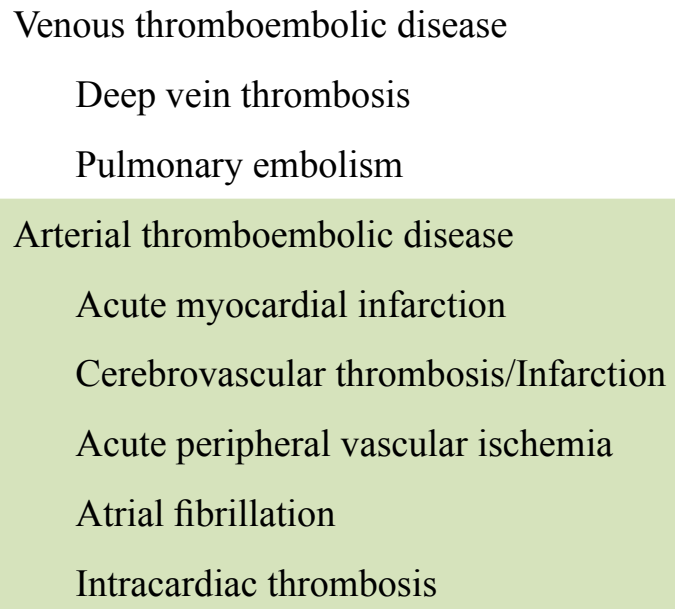

Venous thromboembolic disease

Deep vein thrombosis

Pulmonary embolism

Arterial thromboembolic disease

Acute myocardial infarction

Cerebrovascular thrombosis/Infarction

Acute peripheral vascular ischemia

Atrial fibrillation

Intracardiac thrombosis

Congestive heart failure

Disseminated intravascular coagulation

Tissue ischemia/necrosis secondary to surgery/trauma

Use of thrombolytic agents

Severe infection/Sepsis/Systemic inflammatory response syndrome

\section{Malignancy}

Renal disease

Acute renal failure

Renal vein thrombosis

With underlying cardiovascular disease

Hepatic Insufficiency

Normal pregnancy, eclampsia, pre-eclampsia

PE involves segmental or sub-segmental arteries. A normal helical CT does not completely exclude the diagnosis of PE and is similar to a "low-probability" V/Q scan. Numerous studies have shown, however, that there is a low risk of PE following a negative CTPA. ${ }^{33-36}$ While imperfect, this test is currently considered the "gold standard" for radiographic confirmation or exclusion of PE. Chronic airflow obstruction also does not affect the diagnostic performance of CTA or pulmonary angiography. ${ }^{28} \mathrm{~A}$ coronal cut from the CTA of patient $B$ showing a large proximal right main pulmonary artery thromboembolism is shown in Figure 1.

Pulmonary angiography was previously the "standard" for diagnosis of pulmonary embolism but is a costly, invasive procedure with many potential serious side effects and a reported mortality rate of

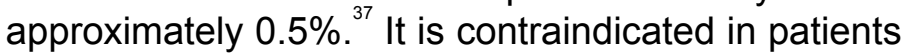
with renal impairment or a known allergy to the contrast material, and many health care institutions do 


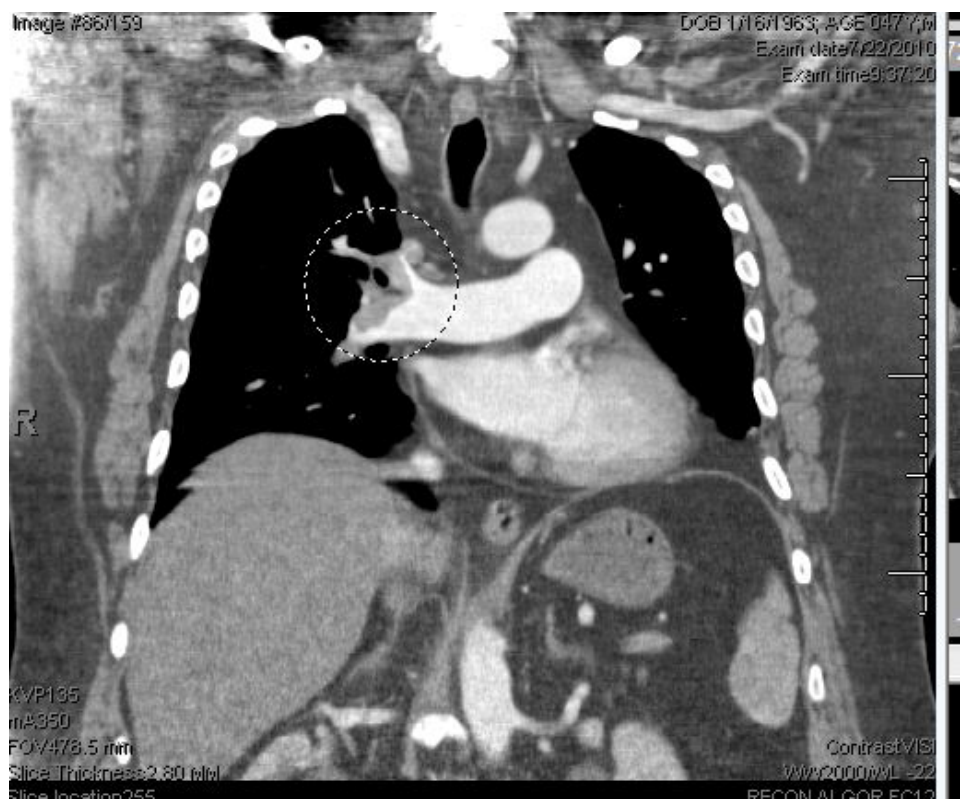

Figure 1. CT Pulmoary angiogram study showing large proximal right main pulmonary artery thromboembolism

not have access to this test. Pulmonary angiography for the diagnosis of PE has been largely supplanted by the widespread availability of CT-PA.

A summary of advantages and disadvantages of the available diagnostic studies for PE in patients with suspected or previously diagnosed airflow obstruction is shown in Table 3 , and a suggested diagnostic algorithm for PE in these patients is shown in Figure 2.

Our cases highlight several important points for diagnosing $P E$ in patients either diagnosed with or suspected of having underlying airflow obstruction. All four patients presented with a presumed exacerbation of airflow obstruction as a consequence of bronchospasm and/or infection. Pulmonary embolism was suspected only after each patient failed to improve clinically, despite initial therapy directed at the presumed exacerbating factor(s). It is instructive that three of the patients were non-smokers, and two did not have a previous diagnosis of obstructive lung disease. In spite of the lack of an established diagnosis of airflow obstruction, these two patients were presumed to have exacerbation of airflow obstruction at presentation, underscoring the non-specific nature of PE symptoms and the similarity between PE symptoms and symptoms of airflow obstruction. Three of the four patients had an abnormal D-dimer that helped direct further evaluation for PE. Although the fourth patient had a normal D-dimer level, the clinical suspicion for PE was sufficiently high in this patient to continue an aggressive diagnostic strategy for PE. This patient illustrates another important point, namely that the aggressiveness with which the diagnosis of $P E$ is pursued is always driven by the underlying clinical suspicion for PE. The presence of OSA in our patients also likely increased their risk for $P E$ and should be considered an additional risk factor for PE. ${ }^{19-20}$ This association adds one more reason to an already long list for carefully assessing all patients for OSA.

There are multiple published guidelines for treating PE. ${ }^{38-40}$ Therapy begins with timely evaluation of the airway, breathing, and circulation in conjunction with provision of supplemental oxygen. An initial bolus of intravenous fluid should be used for patients with hypotension (SBP $<90 \mathrm{mmHg}$ or a drop in SBP $>40 \mathrm{mmHg}$ from baseline), and IV vasopressors may be needed if hypotension persists despite the initial fluid resuscitation.

Anticoagulant therapy is the mainstay of treatment for venous thromboembolism including PE and produces a passive reduction in thrombus size. Many pharmaceutical agents are available, including unfractionated heparin, low-molecular weight heparin, and warfarin, as well as newer agents, including dabigatran, rivaroxaban, apixaban, and fondaparinux. ${ }^{38-40}$ For patients with suspected or known heparin-induced thrombocytopenia, a non-heparin based anticoagulant should be used such as lepirudin, argatroban, or bivalirudin. ${ }^{40-41}$ A recent meta-analysis of clinical and safety outcomes with various venous thromboembolism therapies suggests that an unfractionated heparin/vitamin $\mathrm{K}$ antagonist regimen is less effective, while rivaroxaban and apixaban regimens are associated with a lower risk of bleeding. ${ }^{42}$

In contrast to anticoagulant therapy, thrombolytic therapy actively reduces thrombus size by in- 
Table 3: Advantages and disadvantages of diagnostic studies for pulmonary embolism in patients with underlying lung disease

\begin{tabular}{|c|c|c|}
\hline & Advantages & Disadvantages \\
\hline D-dimer & $\begin{array}{l}\text { Low-cost, non-invasive } \\
\text { Sensitivity }=95 \% \\
\text { Specificity }=40-68 \%\end{array}$ & $\begin{array}{l}\text { Rule out VTE in low probability } \\
\text { patient when negative, but must } \\
\text { perform further work up when } \\
\text { positive } \\
\text { Multiple causes of a false posi- } \\
\text { tive test (Table } 3 \text { ) }\end{array}$ \\
\hline $\begin{array}{l}\text { Lower Extremity Ve- } \\
\text { nous Doppler }\end{array}$ & $\begin{array}{l}\text { Low-cost, non-invasive } \\
\text { Detection of asymptomatic } \\
\text { DVT is indirect evidence of PE } \\
\text { High sensitivity and specificity } \\
\text { for DVT }\end{array}$ & $\begin{array}{l}\text { May be negative in patients } \\
\text { with proven PE } \\
\text { Test is ultrasound technician/ } \\
\text { radiologist dependent }\end{array}$ \\
\hline $\begin{array}{l}\text { CT-Pulmonary Angio- } \\
\text { gram }\end{array}$ & $\begin{array}{l}\text { High sensitivity and PPV of } \\
85 \% \text { with main or lobar artery } \\
\text { PE } \\
\text { Can give information about } \\
\text { other etiologies for dyspnea }\end{array}$ & $\begin{array}{l}\text { High cost, Renal toxicity } \\
\text { Radiation exposure } \\
\text { May miss PE in smaller arterial } \\
\text { branches }\end{array}$ \\
\hline V/Q Scan & Non-invasive & $\begin{array}{l}\text { Patient factors and underlying } \\
\text { lung disease may affect results } \\
\text { Only } 25 \% \text { of patients have a } \\
\text { normal scan } \\
65 \% \text { of scans are indeterminate } \\
\text { Perfusion defects are non- } \\
\text { specific }\end{array}$ \\
\hline $\begin{array}{l}\text { Interventional Angio- } \\
\text { gram }\end{array}$ & $\begin{array}{l}\text { Gold standard for diagnosis of } \\
\text { PE }\end{array}$ & $\begin{array}{l}\text { High cost, invasive } \\
\text { Renal toxicity, requires exper- } \\
\text { tise }\end{array}$ \\
\hline
\end{tabular}




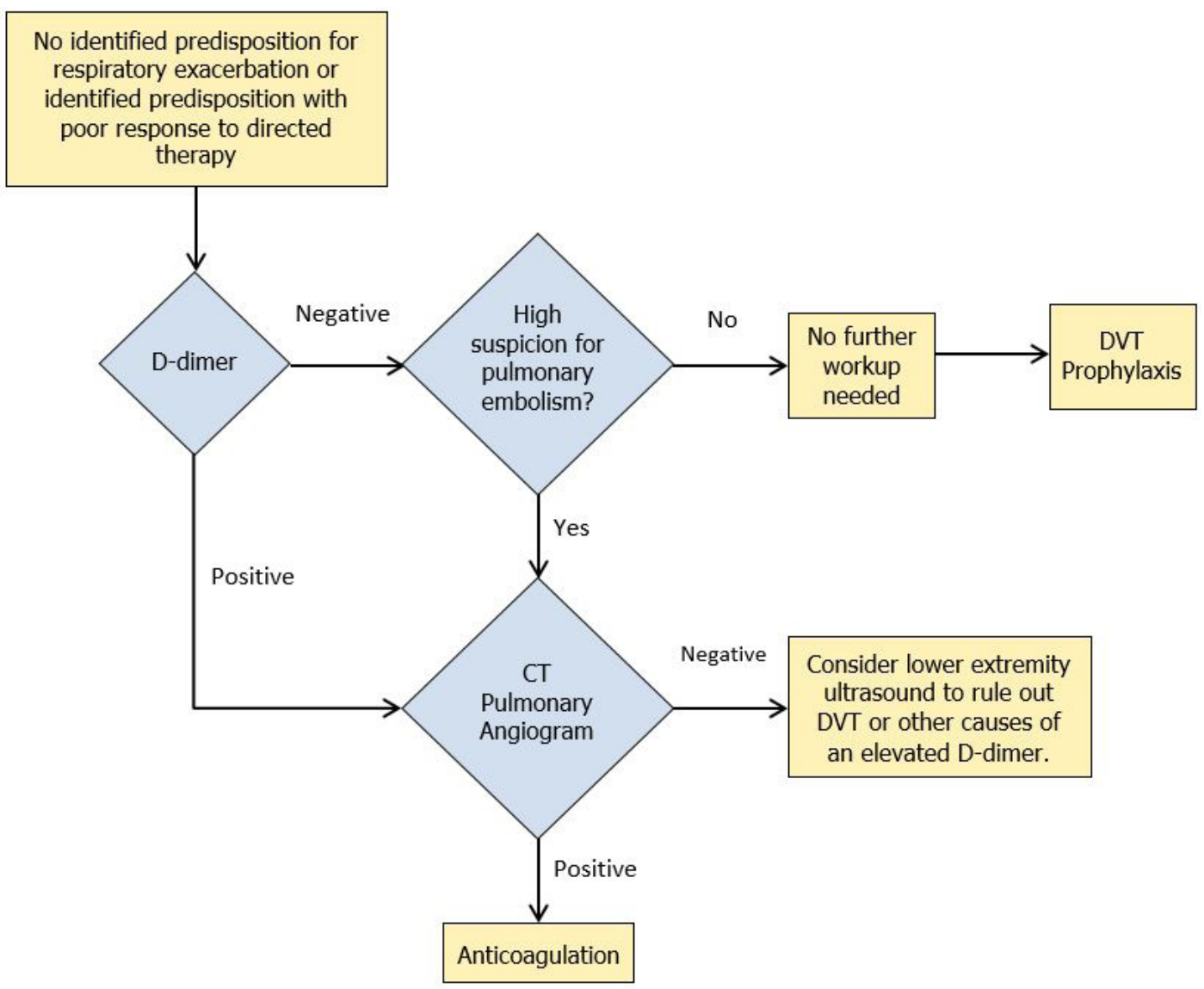

Figure 2. Algorithm for evaluation and treatment of pulmoary embolism in patients with exacerbation of presumed or previously diagnosed airflow obstruction.

creasing the conversion of plasminogen into plasmin which then cleaves fibrin molecules. ${ }^{43}$ Thrombolysis is usually reserved for clinically unstable patients since it is associated with a significant risk of bleeding events which may be fatal or cause significant morbidity. Studies have shown that treatment with fibrinolysis produces faster restoration of lung perfusion and, thereby, provides a more rapid improvement in clinical symptoms.

Surgical embolectomy remains an alternative to pharmaceutical thrombolysis in clinically unstable patients with massive or sub-massive PE and evidence of RV dysfunction when either thrombolysis fails or is contraindicated.
Finally, for patients who are not candidates for surgical embolectomy, anticoagulation, thrombolysis, or have had previous bleeding events or recurrent VTE while on anticoagulation, inferior vena cava filters may be used. Notably, IVC filter use has increased in recent decades ${ }^{50-51}$ while the benefits of IVC filters remain controversial. ${ }^{50-53}$ The PREPIC Trial showed that IVC filters reduced the incidence of recurrent PE at 12 days and eight years, but were also associated with increased recurrent DVT at two years with no overall effect on mortality.

Preventing lower extremity DVT is the most important measure we can undertake to prevent PE. In hospitalized patients, anticoagulant DVT prophylaxis is recommended for acutely-ill medical patients 
at increased risk of thrombosis. ${ }^{54}$ The level of risk is based on a score derived from a risk assessment model that does not include either COPD or OSA. Age $\geq 70$ years and obesity (BMI $\geq 30$ ), risk factors commonly found in COPD and OSA patients, are included in this model, as is respiratory failure, but the combination of these three risk factors does not produce a score deemed "high risk." Due to the inherent limitation in mobility associated with COPD and OSA, we suggest that these co-morbid conditions be considered in the assessment of risk for venous thromboembolism and that DVT prophylaxis is indicated for hospitalized COPD and OSA patients

\section{SUMmARY}

Patients with presumed or established airflow obstruction frequently present with worsening respiratory symptoms attributed initially to exacerbation of the underlying airflow obstruction. For patients without a confirmed etiology for the exacerbation, such as bronchitis, pneumonia, or bronchospasm, or for those who do not respond favorably to therapy directed at the presumed exacerbating factor, PE will be a common finding as these patients frequently do not present with specific subjective or objective clues to the diagnosis of PE. While initial clinical evaluation may reasonably begin with obtaining a D-dimer and/ or Doppler-USG of the legs, it is the clinical suspicion of $\mathrm{PE}$ by the health care provider that remains the critical element for diagnosis of PE. Prompt diagnosis and treatment of PE can improve the patient's short and long term prognosis.

The Southwest Respiratory and Critical Care Chronicles 2014;2(8)
Author Affiliation: Robert B Tompkins MD, Vaughn Harris MD and Clayton Brown MD are in the departments of Family Medicine at The University of Texas Health Northeast Medical Center, Tyler TX. David E Griffith is in the department of internal medicine at The University of Texas Health Northeast Medical Center, Tyler TX.

Received: 09/21/2014

Accepted: 09/29/2014

Reviewers: Gilbert Berdine MD, Kenneth Nugent MD

Published electronically: 10/15/2014

Conflict of Interest Disclosures: None

\section{REFERENCES}

1. Rizkallah J, Man SF, Sin DD. Prevalence of pulmonary embolism in acute exacerbations of COPD: a systematic review and meta-analysis. Chest 2009 Mar; 135(3):786-93.

2. Tillie-Leblond I, Marquette $\mathrm{CH}$, Perez T, Scherpereel A, Zanetti C, Tonnel AB, Remy-Jardin M. Pulmonary embolism in patients with unexplained exacerbation of chronic obstructive pulmonary disease: prevalence and risk factors. Ann Intern Med 2006 Mar 21; 144(6):390-6.

3. Chen WJ, Lin CC, Lin CY, Chang YJ, Sung FC, Kao CH, Yeh JJ. Pulmonary embolism in chronic obstructive pulmonary disease: a population-based cohort study. COPD 2014 Aug; 11(4):438-43.

4. Klok FA, Zondag W, van Kralingen KW, van Dijk AP, Tamsma JT, Heyning FH, et al. Patient outcomes after acute pulmonary embolism. A pooled survival analysis of different adverse events. Am J Respir Crit Care Med 2010 Mar 1; 181(5):501-6.

5. Horlander KT, Mannino DM, Leeper KV. Pulmonary embolism mortality in the United States, 1979-1998: an analysis using multiple-cause mortality data. Arch Intern Med 2003 Jul 28; 163(14):1711-7.

6. Nijkeuter M, Söhne M, Tick LW, Kamphuisen PW, Kramer $\mathrm{MH}$, Laterveer L, et al.The natural course of hemodynamically stable pulmonary embolism: Clinical outcome and risk factors in a large prospective cohort study. Chest 2007 Feb; 131(2):517-23. 7. Goldhaber SZ, Visani L, De Rosa M. Acute pulmonary embolism: clinical outcomes in the International Cooperative Pulmonary Embolism Registry (ICOPER). Lancet 1999 Apr 24; 353(9162):1386-9. 
8. ten Wolde M, Söhne M, Quak E, Mac Gillavry MR, Büller HR. Prognostic value of echocardiographically assessed right ventricular dysfunction in patients with pulmonary embolism. Arch Intern Med 2004 Aug 9-23; 164(15):1685-9.

9. Casazza F, Becattini C, Bongarzoni A, Cuccia C, Roncon L, Favretto G, et al. Clinical features and short term outcomes of patients with acute pulmonary embolism. The Italian Pulmonary Embolism Registry (IPER). Thromb Res 2012 Dec; 130(6):84752.

10. Vanni S, Nazerian P, Pepe G, Baioni M, Risso M, Grifoni G, et al. Comparison of two prognostic models for acute pulmonary embolism: clinical vs. right ventricular dysfunction-guided approach. $J$ Thromb Haemost 2011Oct; 9(10):191623.

11. Grifoni S, Vanni S, Magazzini S, Olivotto I, Conti A, Zanobetti $\mathrm{M}$, et al. Association of persistent right ventricular dysfunction at hospital discharge after acute pulmonary embolism with recurrent thromboembolic events. Arch Intern Med 2006 Oct 23; 166(19):2151-6.

12. Baum GL, Fisher FD. The relationship of fatal pulmonary insufficiency with cor pulmonale, right sided mural thrombi and pulmonary emboli: a preliminary report. Am J Med Sci 1960 Nov; 240:609-12.

13. Mitchell RS, Silvers GW, Dart GA, Petty TL, Vincent TN, Ryan SF, Filley GF. Clinical and morphologic correlations in chronic airway obstruction. Aspen Emphysema Conf 1968;9: 109-23.

14. Lesser BA, Leeper KV Jr, Stein PD, Saltzman HA, Chen $\mathrm{J}$, Thompson BT, et al. The diagnosis of acute pulmonary embolism in patients with chronic obstructive pulmonary disease. Chest 1992 Jul; 102(1):17-22.

15. Shetty R, Seddighzadeh A, Piazza G, Goldhaber SZ. Chronic obstructive pulmonary disease and deep vein thrombosis: a prevalent combination. $J$ Thromb Thrombolysis 2008 Aug; 26(1):3540.

16. Stein PD, Beemath A, Meyers FA, Olson RE. Pulmonary embolism and deep venous thrombosis in hospitalized adults with chronic obstructive pulmonary disease. J Cardiovasc Med (Hagerstown) 2007 Apr; 8(4):253-7.

17. Stein PD, Beemath A, Matta F, Weg JG, Yusen RD, Hales $\mathrm{CA}$, et al. Clinical characteristics of patients with acute pulmonary embolism: data from PIOPED II. Am J Med 2007 Oct; 120(10):871-9

18. Heit JA, O'Fallon WM, Petterson TM, Lohse CM, Silverstein MD, Mohr DN, Melton LJ 3rd. Relative impact of risk factors for deep vein thrombosis and pulmonary embolism: a populationbased study. Arch Intern Med 2002 Jun 10; 162(11):1245-8.

19. Goldhaber SZ, Grodstein F, Stampfer MJ, Manson JE, Colditz GA, Speizer FE, et al. A prospective study of risk factors for pulmonary embolism in women. JAMA $1997 \mathrm{Feb} 26$; 277(8):6425 .
20. Peng YH, Liao WC, Chung WS, Muo $\mathrm{CH}$, Chu CC, Liu CJ, Kao CH. Association between obstructive sleep apnea and deep vein thrombosis / pulmonary embolism: a population-based retrospective cohort study. Thromb Res 2014 Aug; 134(2):340-5.

21. Liak C, Fitzpatrick M. Coagulability in obstructive sleep apnea. Can Respir J 2011 Nov-Dec; 18(6):338-48.

22. Carson JL, Terrin ML, Duff A, Kelley MA. Pulmonary embolism and mortality in patients with COPD. Chest 1996 Nov; 110(5):1212-9.

23. PIOPED Investigators. Value of the ventilation/perfusion scan in acute pulmonary embolism. Results of the prospective investigation of pulmonary embolism diagnosis (PIOPED). JAMA 1990 May 23-30; 263(20):2753-9.

24. Stein PD, Hull RD, Patel KC, Olson RE, Ghali WA, Brant R, et al. D-dimer for the exclusion of acute venous thrombosis and pulmonary embolism: a systematic review. Ann Intern Med 2004 Apr 20; 140(8):589-602.

25. Gibson NS, Sohne M, Gerdes VE, Nijkeuter M, Buller HR. The importance of clinical probability assessment in interpreting a normal d-dimer in patients with suspected pulmonary embolism. Chest.2008 Oct; 134(4):789-93.

26. Crowther MA, Cook DJ, Griffith LE, Meade M, Hanna S, Rabbat $\mathrm{C}$, et al. Neither baseline tests of molecular hypercoagulability nor D-dimer levels predict deep venous thrombosis in critically ill medical-surgical patients. Intensive Care Med 2005 Jan; 31(1):48-55.

27. Stein PD, Woodard PK, Weg JG, Wakefield TW, Tapson VF, Sostman HD, et al. Diagnostic pathways in acute pulmonary embolism: recommendations of the PIOPE II investigators. Am J Med 2006 Dec; 119(12):1048-55.

28. Rathbun SW, Whitsett TL, Vesely SK, Raskob GE. Clinical utility of D-dimer in patients with suspected pulmonary embolism and nondiagnostic lung scans or negative CT findings. Chest 2004 Mar; 125(3):851-5.

29. Hartmann IJ, Hagen PJ, Melissant CF, Postmus PE, Prins MH. Diagnosing acute pulmonary embolism: effect of chronic obstructive pulmonary disease on the performance of D-dimer testing, ventilation/perfusion scintigraphy, spiral computed tomographic angiography, and conventional angiography. ANTELOPE Study Group. Advances in New Technologies Evaluating the Localization of Pulmonary Embolism. Am J Respir Crit Care Med 2000 Dec; 162(6):2232-7

30. Kiely DG, Kennedy NS, Pirzada O, Batchelor SA, Struthers $\mathrm{AD}$, Lipworth BJ. Elevated levels of natriuretic peptides in patients with pulmonary thromboembolism. Respir Med 2005 Oct; 99(10):1286-91.

31. Cavallazzi R, Nair A, Vasu T, Marik PE. Natriuretic peptides in acute pulmonary embolism: a systematic review. Intensive Care Med 2008 Dec; 34(12):214756.

32. Söhne M, Ten Wolde M, Boomsma F, Reitsma JB, Douke- 
tis JD, Büller HR. Brain natriuretic peptide in hemodynamically stable acute pulmonary embolism. J Thromb Haemost 2006 Mar; 4(3):552-6.

33. Rathbun SW, Raskob GE, Whitsett TL. Sensitivity and specificity of helical computed tomography in the diagnosis of pulmonary embolism: a systematic review. Ann Intern Med 2000 Feb 1; 132(3):227-32.

34. Quiroz R, Kucher N, Zou KH, Kipfmueller F, Costello P, Goldhaber SZ, Schoepf UJ. Clinical validity of a negative computed tomography scan in patients with suspected pulmonary embolism: a systematic review. JAMA 2005 Apr 27; 293(16):20127.

35. Moores LK, Jackson WL Jr, Shorr AF, Jackson JL. Metaanalysis: outcomes in patients with suspected pulmonary embolism managed with computed tomographic pulmonary angiography. Ann Intern Med 2004 Dec 7; 141(11):866-74.

36. Tillie-Leblond I, Mastora I, Radenne F, Paillard S, Tonnel AB, Remy J, Remy-Jardin M. Risk of pulmonary embolism after a negative spiral CT angiogram in patients with pulmonary disease: 1-year clinical follow-up study. Radiology 2002 May; 223(2):461-7.

37. Hofmann LV, Lee DS, Gupta A, Arepally A, Sood S, Girgis R, Eng J. Safety and hemodynamic effects of pulmonary angiography in patients with pulmonary hypertension: 10-year singlecenter experience. AJR Am J Roentgenol 2004 Sep; 183(3):77986.

38. Jaff Michael R, McMurtry Sean, Archer Stephen L, Cushman Mary, Goldenberg Neil, Goldhaber Samuel Z, et al. Management of Massive and Submassive Pulmonary Embolism, Iliofemal Deep Vein Thrombosis, and Chronic Thromboembolic Pulmonary Hypertension: A Scientific Statement from the American Heart Association. Circulation 2011; 123: 1788-1830.

39. Torbicki A, Perrier A, Konstantinides S, Agnelli G, Galie N, Pruszczyk $\mathrm{P}$, et al. Guidelines on the diagnosis and management of acute pulmonary embolism: the Task Force for the Diagnosis and Management of Acute Pulmonary Embolism of the European Society of Cardiology (ESC). Eur Heart J 2008; 29:2276-2315. 40. Guyatt GH, Akl EA, Crowther M, Gutterman DD, Schunemann HJ; American College of Chest Physicians. Antithrombotic therapy and prevention of thrombosis: American College of Chest Physicians Evidence-Based Clinical Practice Guidelines (9th Edition). Chest 2012; 141(suppl): 1S-70S.

41. Linkins LA, Dans AL, Moores LK, Bona R, Davidson BL, Schulman S, Crowther M ; American College of Chest Physicians. Treatment and prevention of heparin-induced thrombocytopenia. American College of Chest Physicians Evidence-Based Clinical Practice Guidelines (9th Edition) Chest 2012; 141(suppl): e495SS-e530S.

42. Castellucci LA, Cameron C, Le Gai G, Rodger MA, Coyle D, Wells PS et al. Clinical and safety outcomes associated with treatment of acute venous thromboembolism; A systmeatic review and meta-analysis. JAMA 2014, 312: 1122-1135.

43. Bell WR. Present-Day thrombolytic therapy: therapeutic agents: pharmacokinetics and pharmacodynamics. Rev Cardiovasc Med 2002; 3(suppl 2):S34-S44.

44. Goldhaber SZ, Come PC, Lee RT, Braunwald E, Parker JA, Haire WD, et al. Alteplase versus heparin in acute pulmonary embolism: randomized trial assessing right-ventricular function and pulmonary perfusion. Lancet 1993; 341:507-511.

45. Daniels LB, Parker JA, Patel SR, Grodstein F, Goldhaber SZ. Relation of duration of symptoms with response to thrombolytic therapy in pulmonary embolism. Am J Cardiology 1997; 80:184188.

46. Schreiber D, Lin B, Liu G, Briese B, Hiestand B, Slatter D, et $a l$. Variation in therapy and outcomes in massive pulmonary embolism from the Emergency Medicine Pulmonary Embolism in the Real World Registry (EMPEROR). Acad Emerg Med 2009; 16(S77).

47. Sukhija R, Aronow WS, Lee J, Kakar P, McClung JA, Levy JA, Belkin RN. Association of right ventricular dysfunction with in-hospital mortality in patients with acute pulmonary embolism and reduction in mortality in patients with right ventricular dysfunction by pulmonary embolectomy. Am J Cardiology 2005; 95:695-696.

48. Stein PD, Alnas M, Beemath A, Patel NR. Outcome of pulmonary embolectomy. Am J Cardiology 2007; 99:421-423.

49. Leacche M, Unic D, Goldhaber SZ, Rawn JD, Arnaki SF, Couper GS, et al. Modern surgical treatment of massive pulmonary embolism: results of 47 consecutive patients after rapid diagnosis and aggressive surgical approach. $J$ Thoracic Cardiovasc Surg 2005; 129:1018-1023.

50. Stein PD, Kayali F, Olson RE. Twenty-one year trends in the use of inferior vena cava filters. Arch Intern Med 2004; 164:1541-1545.

51. Jaff MR, Goldhaber SZ, Tapson VF. High utilization rate of vena cava filters in deep venous thrombosis. Thromb Haemost 2005; 93:1117-1119.

52. Decousus H, Leizorovicz A, Parent F, Page Y, Tardy B, Girard P, Laporte S, Faivre R, Charbonnier B, Barral FG, Huet Y, Simonneau G. A clinical trial of vena caval filters in the prevention of pulmonary embolism in patients with proximal deep-vein thrombosis: Prevention du Risque d'Embolie Pulmonaire par Interruption Cave Study Group. N Engl J Med 1998; 338:409-415. 53. White RH, Zhou H, Kim J, Romano PS. A population-based study of the effectiveness of inferior vena cava filter use among patients with venous thromboembolism. Arch Intern Med 2000; 160:2033-2041.

54. Kahn SR, Lim W, Dunn AS, Cushman M, Dentali F, Akl EA, Cook DJ, Balekian AA, Klein RC, Le H, Schulman S, Murad $\mathrm{MH}$; American College of Chest Physicians. Prevention of VTE 
in nonsurgical patients: Antithrombotic Therapy and Prevention of Thrombosis, 9th ed: American College of Chest Physicians Evidence-Based Clinical Practice Guidelines. Chest 2012 Feb; 141(2 Suppl):e195S-226S. 